\title{
ANALISIS PENGARUH BEBAN PAJAK KINI, ASET PAJAK TANGGUHAN, DISCRETION ACCRUAL, DAN TAX PLANNING TERHADAP MANAJEMEN LABA
}

\author{
T. Ricy Rikhad Suheri ${ }^{1}$, Dewi Fitriyani ${ }^{2}$, Dedy Setiawan ${ }^{3}$ \\ ${ }^{1}$ Alumni Fakultas Ekonomi, Universitas Jambi \\ ${ }^{2}$ Fakultas Ekonomi dan Bisnis, Universitas Jambi \\ ${ }^{3}$ Fakultas Sains dan Teknologi, Universitas Jambi \\ e-mail: dewi_fitriyani@unja.ac.id
}

\begin{abstract}
Abstrak
Tujuan penelitian ini adalah untuk menganalisis pengaruh beban pajak kini, aset pajak tangguhan, discretionary accrual, dan tax planning terhadap manajemen laba. Populasi penelitian adalah perusahan manufaktur yang terdaftar di Bursa Efek Indonesia (BEI) dengan menggunakan metode purposive random sampling. Ada 39 perusahaan dari 142 perusahaan yang diambil sebagai sampel penelitian. Pengujian hipotesis menggunakan regresi logistik dengan software SPSS versi 22.0. Hasil penelitian dengan regresi logistik menunjukkan bahwa beban pajak kini, aset pajak tangguhan, discretionary accrual, dan tax planning berpengaruh secara simultan terhadap manajemen laba. Dalam uji parsial hanya beban pajak kini dan tax planning yang berpengaruh terhadap manajemen laba.
\end{abstract}

Kata kunci : manajemen laba, beban pajak kini, aset pajak tangguhan, discretionary accrual, tax planning

\begin{abstract}
The aim of this research is to analyzed the effect of current tax expense, deferred tax assets, discretinary accrual, and tax planning to earnings management. The research population is manufacturing companies listed on the Indonesian Stock Exchange in the period 2011-2014 by using purposive random sampling. There are 39 companies out of 142 companies that were taken as samples. Hypothesis testing using a Logistic Regression with SPSS software version 22.0. The result of this research which use the logistic regression showed that both of deferred tax expense and tax planning have a significant effect to earning management, but while deferred tax asset and discretionary accrual doesn't have significant effect to earning management.
\end{abstract}

Keywords: Earning management, deferred tax expense, deferred tax asset, discretionary accrual, tax planning

\section{PENDAHULUAN}

Laporan keuangan merupakan sarana komunikasi yang berguna sebagai penghubung pihak-pihak yang berkepentingan terhadap perusahaan baik pihak eksternal maupun pihak internal (Subekti, 2005). Dari laporan keuangan ini, salah satu parameter untuk mengukur kinerja suatu perusahaan apakah baik atau tidak yaitu dengan melihat laba (earning) perusahaan tersebut. Sebagaimana yang disebutkan dalam Statement of Financial Accounting Concept (SFAC) No.1 Bahwa informasi laba pada umumnya merupakan perhatian utama dalam menafsir kinerja atau pertanggungjawaban manajemen dan informasi laba membantu pemilik atau pihak lain melakukan penaksiran terhadap earning power perusahaan dimasa yang akan datang. 
Informasi laba dapat dijadikan sebagai alat bantu dalam menilai kinerja manajemen perusahaan, melakukan estimasi kemampuan laba yang representatif dalam jangka panjang dan menaksir risiko-risiko investasi. Walaupun semua isi dari laporan keuangan bermanfaat bagi para pemakai, namun biasanya perhatian lebih banyak ditujukan pada informasi laba.

Manajemen menyadari pentingnya informasi laba sehingga manajemen cenderung melakukan disfunctional behaviour (perilaku tidak semestinya) yang dipengaruhi oleh adanya asimetri informasi dalam konsep teori keagenan di mana tiap-tiap pihak, baik principal selaku pemegang saham maupun agent selaku manajemen perusahaan mempunyai perbedaan kepentingan dan ingin memperjuangkan kepentingan masing-masing sehingga mendorong manajer untuk melakukan manajemen laba atau manipulasi atas laba (Assih dan Gudono, 2000).

Proses manipulasi laba dilakukan dengan mengurangi fluktuasi laba dan memaksimalkan atau meminimalkan laba tergantung motivasi manajer dalam memanipulasi laba tersebut. Salah satu motivasi manajer dalam melakukan manajemen laba adalah motivasi penghematan pajak (taxation motivation) (Scott, 2000). Menurut Sulistiawan, dkk (2011) motivasi untuk kepentingan pajak termasuk hal yang memotivasi individu atau badan usaha melakukan tindakan manajemen laba. Perusahaan cenderung melaporkan dan menginginkan untuk menyajikan laporan laba fiskal yang lebih rendah dari nilai yang sebenarnya. Kecenderungan ini memotivasi manajer untuk bertindak kreatif melakukan tindakan manajemen laba agar seolah-olah laba fiskal yang dilaporkan memang lebih rendah tanpa melanggar aturan dan kebijakan akuntansi perpajakan. Sebagaimana yang disebutkan dalam Pernyataan Standar Akuntansi Keuangan (PSAK) No. 46 bahwa manajemen bebas dalam menentukan pilihan kebijakan akuntansi dalam menentukan besaran pencadangan beban/penghasilan pajak tangguhan. Pencadangan beban/penghasilan pajak tangguhan terjadi akibat adanya perbedaan pengakuan antara standar akuntansi dengan peraturan perpajakan. Hal ini memberikan celah bagi manajemen dalam melakukan tindakan manajemen laba (Perwita, dkk., 2013).

Pajak merupakan tumpuan terbesar dari beban belanja APBN Indonesia. Pengeluaran negara yang makin meningkat juga berdampak pada target pajak yang terus meningkat tiap tahunnya. Sektor manufaktur juga memberikan kontribusi yang terus meningkat pada penerimaan pajak khususnya pajak penghasilan. Peningkatan pertumbuhan sektor manufaktur tidak diikuti secara seimbang oleh peningkatan penerimaan pajak yang seharusnya terjadi. Kesenjangan penerimaan yang tersebut disebabkan oleh rendahnya kepatuhan penyetoran pajak atau masih banyaknya transaksi yang tidak tercatat (underground economy) dan tren manajemen laba (Perwita, dkk., 2013).

Penelitian tentang manajemen laba telah banyak dilakukan, hasil dari penelitian tersebut tidak memberikan kesimpulan yang konsisten terhadap faktor-faktor yang dapat mempengaruhi perusahaan melakukan tindakan manajemen laba (earning management). Faktor-faktor tersebut diantaranya: beban pajak kini, aset pajak tangguhan, discretionary accrual dan tax planning. Mengacu pada penelitian sebelumnya, Deviana (2010) menyatakan bahwa beban pajak kini berpengaruh signifikan terhadap adanya indikasi praktek manajemen laba (earning management). Penelitian tersebut sejalan dengan penelitian yang dilakukan oleh Widhiastuti (2013) yang menunjukkan bahwa beban pajak kini berpengaruh terhadap manajemen laba (earning management), serta penelitian yang telah dilakukan oleh Triono (2014) yang menyatakan beban pajak kini berpengaruh positif dan signifikan terhadap manajemen laba (earning management). Sedangkan pada penelitian Rahmi (2013) menunjukkan hasil yang berbeda bahwa beban pajak kini tidak mampu dalam memprediksi manajemen laba (earning management). 
Suandi (2011) menjelaskan bahwa apabila ada kemungkinan pembayaran pajak yang lebih kecil pada masa yang akan datang maka berdasarkan standar akauntansi yang berlaku umum dapat dianggap sebagai suatu aset. Pengakuan aset tangguhan didasarkan pada fakta adanya kemungkinan pemulihan aset mengakibatkan pembayaran pajak pada periode mendatang menjadi lebih kecil sebagai akibat pemulihan aset yang tidak memiliki konsekuensi pajak. Studi Bauman et al. (2001) menunjukkan cadangan aset pajak tangguhan digunakan untuk melakukan manajemen laba dengan tujuan invoke an earnings big bath.

Hasil penelitian Bauman et al. (2001) menunjukkan bahwa aset pajak tanguhan berpengaruh terhadap adanya praktek manajemen laba dengan cadangan aset pajak tanguhan sebagai indikatornya. Sedangkan pada penelitian Erwati, dkk (2013) menunjukan bahwa aset pajak tangguhan tidak memiliki kemampuan dalam memprediksi adanya manajemen laba. Sejalan dengan penelitian Erwati, dkk (2013), Dewi \& Feni (2012) dan Suranggane (2007) menunjukkan bahwa aset pajak tangguhan tidak mempunyai pengaruh yang signifikan terhadap manajemen laba.

Selain beban pajak kini dan aset pajak tangguhan, dalam penelitian ini juga menggunakan discretionary acrual sebagai faktor yang mempengaruhi tindakan manajemen laba (earning management). Discretionary Accrual adalah pengakuan akrual laba atau beban yang bebas tidak diatur dan merupakan pilihan kebijakan manajemen. Discretionary acrual merupakan akrual yang muncul akibat diskresi manajemen atau berada di bawah kebijakan manajemen. Hal ini biasanya digunakan sebagai pengukur dalam manajemen laba dan besarannya merupakan hasil modifikasi angka-angka pada laporan keuangan untuk memenuhi tujuan manajemen sehingga keberadaan discretionary accrual menandakan rendahnya kualitas laba. Manajemen bebas untuk mengurangi atau meningkatkan pelaporan laba yang sulit dideteksi karena sifatnya yang kontekstual dan subjektif (Suranggane, 2007).

Maka dari hasil tersebut, menghasilkan asimeteri informasi antara manajemen dengan pemilik saham yang membuat informasi keuangan menjadi tidak relevan dan tidak dapat digunakan sebagai pengambilan keputusan investasi.

Budiman (2013) menjelaskan bahwa akrual berpengaruh terhadap praktik manajemen laba. Hal tersebut sejalan dengan hasil penelitian Suranggane (2007) menunjukan bahwa akrual memiliki pengaruh yang signifikan pada terjadinya manajemen laba dengan tingkat signifikansi sebesar 5 persen. Sedangkan pada penelitian Dewi \& Feni (2012) menyatakan bahwa akrual tidak mempunyai pengaruh yang signifikan terhadap manajemen laba. Hasil ini didukung oleh penelitian Erwati, dkk (2013) yang menyatakan akrual tidak mampu memprediksi praktik manajemen laba dengan tingkat signifikansi sebesar 0,977.

Penelitian ini juga meneliti pengaruh perencanaan pajak terhadap manajemen laba karena perencanaan pajak merupakan salah satu upaya untuk meminimalisasi beban pajak. Upaya meminimalkan pajak sering disebut dangan perencanaan pajak (tax planning) atau tax shletering. Umumnya perencanaan pajak merujuk pada proses merekayasa usaha dan transaksi wajib pajak (WP) supaya utang pajak berada dalam jumlah yang minimal tetapi masih dalam bingkai peraturan perpajakan.

Dalam pelaksanaannya terdapat perbedaan antara WP dan pemerintah. WP berusaha untuk membayar pajak sekecil mungkin karena dengan membayar pajak berarti mengurangi kemampuan ekonomis WP. Di lain pihak, pemerintah memerlukan dana untuk membiayai penyelenggaraan pemerintahan, yang sebagian besar berasal dari penerimaan pajak. Bagi perusahaan, pajak merupakan beban yang akan mengurangi jumlah laba bersih.

Ulfah (2013) menjelaskan bahwa perencanaan pajak (tax planning) memiliki pengaruh positif terhadap manajemen laba. Hal ini sejalan dengan penelitian Sumomba (2010) yang menyatakan bahwa perencanaan pajak (tax planning) memiliki pengaruh terhadap praktik manajemen laba. Sedangkan penelitian yang dilakukan oleh Aditama \& Purwaningsih (2013) 
menyatakan hasil yang berbeda bahwa perencanaan pajak (tax planning) tidak berpengaruh positif terhadap manajemen laba.

Penelitian tentang faktor-faktor yang mempengaruhi praktik manajemen laba (earning management) pada perusahaan yang terdaftar di Bursa Efek Indonesia sejauh ini telah banyak dilakukan, namun hasil penelitian-penelitian tersebut belum konsisten satu sama lain sehingga peneliti tertarik untuk menguji kembali faktor-faktor yang berpengaruh terhadap praktik manajemen laba. Maka dari itu peneliti bermaksud untuk mereplikasi penelitian yang telah dilakukan oleh Erwati, dkk tahun 2013. Hal yang membedakan penelitian ini dengan penelitian sebelumnya adalah pengurangan variabel beban pajak tangguhan, alasan dikurangkannya variabel beban pajak tangguhan karena pada observasi data awal, sampel yang didapat dengan menggunakan teknik purposive sampling tidak cukup mewakili populasi penelitian.

Selain itu, penelitian ini juga menambahkan variabel beban pajak kini dan perencanaan pajak (tax planning), alasan ditambahnya variabel beban pajak kini mengacu pada penelitian yang telah dilakukan oleh Deviana (2010), Widhiastuti (2013) dan Triono (2014) yang meneliti mengenai pengaruh beban pajak kini terhadap manajemen laba, selanjutnya alasan ditambahnya variabel perencanaan pajak (tax planning) mengacu pada penelitian yang telah dilakukan oleh Sumomba (2010), Ulfah (2013) dan Aditama dan Purwaningsih (2013) yang meneliti mengenai pengaruh perencanaan pajak (tax planning) terhadap manajemen laba,

Populasi perusahaan manufaktur masih dijadikan objek penelitian dikarenakan perusahaan manufaktur merupakan perusahaan yang memiliki aktivitas produksi yang berkesinambungan, sehingga dibutuhkan pengelolaan modal kerja dan aset yang baik, sehingga rentabilitas ekonominya tinggi, yang pada gilirannya akan menarik investor untuk menanamkan modalnya. Di samping itu, perusahaan manufaktur sangat rentan terhadap perkembangan ekonomi internasional dan memiliki persaingan bisnis yang kuat.

\section{TINJAUAN PUSTAKA}

\section{Teori Agensi}

Agency theory memiliki asumsi bahwa masing-masing individu semata-mata termotivasi oleh kesejahteraan dan kepentingan dirinya sendiri. Pihak principal termotivasi mengadakan kontrak untuk menyejahterakan dirinya melalui pembagian dividen atau kenaikan harga saham perusahaan. Agent termotivasi untuk meningkatkan kesejahteraannya melalui peningkatan kompensasi. Konflik kepentingan semakin meningkat ketika principal tidak memiliki informasi yang cukup tentang kinerja agent karena ketidakmampuan principal memonitor aktivitas agent dalam perusahaan. Sedangkan agentmempunyai lebih banyak informasi mengenai kapasitas diri, lingkungan kerja, dan perusahaan secara keseluruhan. Hal inilah yang mengakibatkan adanya ketidakseimbangan informasi yang dimiliki oleh principal dan agent dan dikenal dengan istilah asimetri informasi. Asimetri informasi dan konflik kepentingan yang terjadi antara principal dan agent mendorong agent untuk menyembunyikan beberapa informasi yang tidak diketahui oleh principal dan menyajikan informasi yang tidak sebenarnya kepada principal, terutama informasi tersebut berkaitan dengan pengukuran kinerja agent.

\section{Manajemen Laba}

Menurut Belkaoui (2007) manajemen laba adalah potensi penggunaan manajemen akrual dengan tujuan memperoleh keuntungan pribadi. Belkaoui (2007) menyatakan manajemen laba sebagai tambahan terhadap penggunaan akrual yang tidak diharapkan dan 
akrual pilihan sebagai suatu substitusi untuk manajemen laba, banyak penelitian menunjukkan bukti di mana akrual spesifik atau metode akuntansi digunakan untuk manajemen laba.

Manajer dapat mempengaruhi pelaporan keuangan dengan memanfaatkan kelemahan yang inheren dalam akuntansi itu sendiri. Dalam hal ini, manajer mungkin terlibat dalam beragam pola manajemen laba. Pola-pola manajemen laba dikemukan Scott (1997), antara lain: Taking a bath, income minimization, income maximization, dan income smoothing.

\section{Beban Pajak Kini}

Pajak kini (current tax) adalah jumlah yang harus dibayar oleh wajib pajak (Suandy, 2011). Beban pajak kini adalah jumlah pajak penghasilan terutang atas penghasilan kena pajak pada satu periode. Besanya dihitung dari penghasilan kena pajak yang sebelumnya telah memperhitungkan adanya beda tetap sekaligus beda waktu, dikalikan dengan tarif pajak yang berlaku. Penghasilan kena pajak atau laba fiskal diperoleh dari hasil koreksi fiskal terhadap laba bersih sebelum pajak berdasarkan laporan keuangan komersial (laporan akuntansi). Koreksi fiskal harus dilakukan karna adanya perbedaan perlakukan atas pendapatan maupun biaya yang berbeda antara standar akuntansi dengan peraturan perpajakan yang berlaku.

Perbedaan antara laba akuntansi dan penghasilan kena pajak merefleksikan tingkat kebijakan manajer dalam memanipulasi laba menjadi lebih tinggi (Ettredge et al., 2008 dalam Deviana, 2010), maka beban pajak kini yang menunjukkan efek dari nilai perbedaan tersebut (beda tetap dan beda waktu) digunakan pula sebagai variabel independen pada penelitian ini. Beban pajak kini yang dimaksud dalam penlitian ini diperoleh dari beban pajak kini pada periode laporan keuangan tertentu dibagi dengan total aset periode sebelumnya.

\section{Aset Pajak Tangguhan}

Akuntansi Pajak Tangguhan di Indonesia, akuntansi Pajak Penghasilan diatur dalam Pernyataan Standar Akuntansi Keuangan (PSAK) No. 46 paragraf 07 dimana aset pajak tangguhan didefinisikan sebagai jumlah penghasilan terpulihkan pada periode mendatang sebagai akibat:

1. Perbedaan temporer yang boleh dikurangkan, yaitu perbedaan temporer yang menimbulkan suatu jumlah yang boleh dikurangkan dalam penghitungan laba fiskal periode mendatang pada saat nilai tercatat aset dipulihkan atau nilai tercatat kewajiban tersebut dilunasi; dan

2. Sisa kompensasi kerugian yaitu saldo rugi fiskal yang dapat dikompensasi pada periode yang akan datang.

Apabila ada kemungkinan pembayaran pajak yang lebih kecil pada masa yang akan datang maka berdasarkan standar akauntansi yang berlaku umum dapat dianggap sebagai suatu aset. Suandi (2011). Pengakuan aset tangguhan didasarkan pada fakta adanya kemungkinan pemulihan aset mengakibatkan pembayaran pajak pada periode mendatang menjadi lebih kecil sebagai akibat pemulihan aset yang tidak memiliki konsekuensi pajak. Menurut Agoes dan Trisnawati (2009) aset pajak tangguhan timbul dari pendapatan pajak tangguhan. Aset pajak tangguhan timbul apabila beda waktu menyebabkan terjadiya koreksi positif sehingga beban pajak menurut akuntansi lebih kecil daripada beban pajak menurut peraturan perpajakan.

\section{Discretionary Accrual}

Discretionary Accrual adalah pengakuan akrual laba atau beban yang bebas tidak diatur dan merupakan pilihan kebijakan manajeme. Akrual yang muncul akibat diskresi manajemen atau berada di bawah kebijakan manajemen. Hal ini biasanya digunakan sebagai pengukur dalam manajemen laba dan besarannya merupakan hasil modifikasi angka-angka pada laporan keuangan untuk memenuhi tujuan manajemen sehingga keberadaan discretionary accrual 
menandakan rendahnya kualitas laba. Efek dari kualitas laba yang rendah adalah tidak adanya nilai prediktif dari laba, yang berarti informasi mengenai laba perusahaan ini tidaklah menggambarkan keadaan yang sesungguhnya dari perusahaan sehingga informasi laba menjadi bias bagi pengunanya.

\section{Tax Planning}

Perencanaan pajak (tax planning) merupakan suatu upaya untuk meminimalisasi beban pajak. Perencanaan pajak (tax planning) adalah proses mengorganisasi usaha wajib pajak atau sekelompok wajib pajak sedemikian rupa sehingga utang pajaknya, baik pajak penghasilan maupun pajak lainnya, berada dalam posisi yang paling minimal, sepanjang hal ini dimungkinkan oleh ketentuan peraturan perundang-undangan perpajakan (Zain, 2005). Pada umumnya, perencanaan pajak (tax planning) merujuk kepada proses merekayasa usaha dan transaksi wajib pajak agar hutang pajak berada dalam jumlah yang menimal, tetapi masih dalam bingkai peraturan perpajakan. Namun demikian, perencanaan pajak juga dapat diartikan sebagai perencanaan pemenuhan kewajiban perpajakan secara lengkap, benar, dan tepat waktu sehingga dapat secara optimal menghindari pemborosan sumber daya.

\section{Hubungan Beban Pajak Kini Berpengaruh Terhadap Manajemen Laba}

Adanya perbedaan antara prinsip akuntasi dengan aturan perpajakan akan menimbulkan suatu selisih yang mencakup komponen beda waktu dan beda tetap. Beban pajak kini adalah jumlah pajak penghasilan yang terutang atas penghasilan kena pajak pada satu periode. Besarnya dihitung dari penghasilan kena pajak yang sebelumnya telah memperhitungkan adanya beda tetap sekaligus beda waktu, dikalikan dengan tarif pajak yang berlaku. Oleh karena perbedaan antara laba akuntansi dan penghasilan kena pajak merefleksikan tingkat kebijakan manajer dalam memanipulasi laba menjadi lebih tinggi (Mills dalam Ettredge et al., 2008), maka beban pajak kini yang menunjukkan efek dari nilai perbedaan tersebut (beda tetap dan beda waktu) digunakan pula sebagai variabel independen dalam mendeteksi manajemen laba.

Hasil penelitian Deviana (2010) menyatakan bahwa beban pajak kini berpengaruh signifikan terhadap adanya indikasi praktek manajemen laba (earning management). Penelitian tersebut sejalan dengan penelitian yang dilakukan oleh Widhiastuti (2013) yang menunjukkan bahwa beban pajak kini berpengaruh terhadap manajemen laba (earning management), serta penelitian yang telah dilakukan oleh Triono (2014) yang menyatakan beban pajak kini berpengaruh positif dan signifikan terhadap manajemen laba (earning management). Sedangkan pada penelitian Rahmi (2013) menunjukkan hasil yang berbeda bahwa beban pajak kini tidak mampu dalam memprediksi manajemen laba (earnings management). Dengan demikian dihipotesiskan"

$\mathrm{H}_{1}$ : Beban Pajak Kini berpengaruh terhadap Manajemen Laba

\section{Pengaruh Aset Pajak Tangguhan Terhadap Manajemen Laba}

Suandi (2011) menjelaskan bahwa apabila ada kemungkinan pembayaran pajak yang lebih kecil pada masa yang akan datang maka berdasarkan standar akauntansi yang berlaku umum dapat dianggap sebagai suatu aset. Pengakuan aset tangguhan didasarkan pada fakta adanya kemungkinan pemulihan aset mengakibatkan pembayaran pajak pada periode mendatang menjadi lebih kecil sebagai akibat pemulihan aset yang tidak memiliki konsekuensi pajak. Hasil penelitian Bauman et al. (2001) menunjukkan bahwa aset pajak tanguhan berpengaruh terhadap adanya praktek manajemen laba dengan cadangan aset pajak tanguhan sebagai indikatornya. Sedangkan pada penelitian Erwati, dkk (2013) menunjukan bahwa aset pajak tangguhan tidak memiliki kemampuan dalam memprediksi adanya manajemen laba. Sejalan dengan penelitian Erwati, dkk (2013), Dewi \& Feni (2012) dan 
Suranggane (2007) menunjukkan bahwa aset pajak tangguhan tidak mempunyai pengaruh yang signifikan terhadap manajemen laba. Sehingga dapat dihipotesiskan:

$\mathrm{H}_{3}$ : Aset Pajak Tangguhan berpengaruh terhadap Manajemen Laba.

\section{Pengaruh Discretionary Accrual Terhadap Manajemen Laba}

Discretionary Accrual adalah pengakuan akrual laba atau beban yang bebas tidak diatur dan merupakan pilihan kebijakan manajemen. Akrual yang muncul akibat diskresi manajemen atau berada di bawah kebijakan manajemen. Hal ini biasanya digunakan sebagai pengukur dalam manajemen laba dan besarannya merupakan hasil modifikasi angka-angka pada laporan keuangan untuk memenuhi tujuan manajemen sehingga keberadaan discretionary accrual menandakan rendahnya kualitas laba. Akrual bebas untuk mengurangi atau meningkatka pelaporan laba yang sulit dideteksi karena sifatnya yang kontekstual dan subjektif (Suranggane, 2007).

Dasar akrual umumnya memberikan indikasi yang lebih baik dalam laporan keuangan karena transaksi dan peristiwa keuagan diakui pada saat kejadian dan dicatat dalam catatan akuntansi serta diaporkan dalam laporan keuangan pada periode yang bersangkutan. Maka dari hasil tersebut Asimeteri informasi antara manajemen dengan pemilik saham akan membuat informasi keuangan menjadi tidak relevan dan tidak dapat digunakan sebagai pengambilan keputusan investasi. Berdasarkan uraian tersebut, maka dihipotesiskan:

$\mathrm{H}_{4}$ : Discretionary Accrual berpengaruh terhadap Manajemen Laba.

\section{Pengaruh Perencanaan Pajak (Tax Planning) Terhadap Manajemen Laba}

Umumnya perencanaan pajak merujuk pada proses merekayasa usaha dan transaksi wajib pajak (WP) supaya utang pajak berada dalam jumlah yang minimal tetapi masih dalam bingkai peraturan perpajakan. Ulfah (2013) menyatakan terdapat pengaruh positif antara perencanaan pajak dengan manajemen laba.

Dalam pelaksanaannya terdapat perbedaan antara WP dan pemerintah. WP berusaha untuk membayar pajak sekecil mungkin karena dengan membayar pajak berarti mengurangi kemampuan ekonomis WP. Di lain pihak, pemerintah memerlukan dana untuk membiayai penyelenggaraan pemerintahan, yang sebagian besar berasal dari penerimaan pajak. Bagi perusahaan, pajak merupakan beban yang akan mengurangi jumlah laba bersih. Berdasarkan uraian tersebut dapat dihipotesiskan:

$\mathrm{H}_{4}$ : Perencanaan Pajak (Tax Planning) berpengaruh terhadap Manajemen Laba

\section{METODE PENELITIAN Populasi dan Sampel}

Populasi penelitian ini adalah perusahaan manufaktur yang terdaftar di Bursa Efek Indonesia (BEI) yang terdaftar pada tahun 2011-2014. Teknik pengambilan sampel dilakukan secara purposive sampling agar diperoleh sampel yang sesuai dengan kriteria yang ditentukan. Teknik pengambilan purposive sampling adalah teknik penentuan sampel dengan pertimbangan-pertimbangan tertentu (Sanusi, 2011). Dari hasil seleksi sampel yang dilakukan diperoleh sampel yang layak diteliti sebanyak 39 perusahaan.

\section{Definisi Operasional Variabel}

Variabel yang digunakan dalam penelitian ini terdiri atas 4 variabel independen yaitu Beban Pajak Kini (X1), Aset Pajak Tangguhan (X2), Discretionary Accrual (X3), dan Tax Planning (X4) dan 1 variabel dependen yaitu Manajemen Laba (Y). Berikut tabel operasionalisasi variabel 


\section{Tabel 1 Operasionalisasi Variabel}

\begin{tabular}{|c|c|c|c|}
\hline Variabel & Definisi & Rumus & Skala \\
\hline $\begin{array}{l}\text { Beban Pajak } \\
\text { Kini (X1) }\end{array}$ & $\begin{array}{l}\text { Pajak kini (current tax) adalah jumlah yang } \\
\text { harus dibayar oleh wajib pajak (Suandy, 2011). } \\
\text { Beban pajak kini adalah jumlah pajak } \\
\text { penghasilan terutang atas penghasilan kena } \\
\text { pajak pada satu periode. }\end{array}$ & $\frac{\text { Beban pajak kini }_{i t}}{\text { Total aset }_{t-1}}$ & Rasio \\
\hline $\begin{array}{l}\text { Aset Pajak } \\
\text { Tangguhan } \\
(\mathrm{X} 2)\end{array}$ & $\begin{array}{l}\text { Aset yang timbul apabila beda waktu } \\
\text { menyebabkan terjadinya koreksi positif sehingga } \\
\text { beban pajak menurut akuntansi lebi kecil } \\
\text { daripada beban pajak menurut peraturan } \\
\text { perpajakan. }\end{array}$ & $\frac{\Delta \text { Aset pajak tangguhan }_{i t}}{\text { Aset pajak tangguhan }}$ & Rasio \\
\hline $\begin{array}{l}\text { Discretionary } \\
\text { Accrual (X3) }\end{array}$ & $\begin{array}{l}\text { pengakuan akrual laba atau beban yang bebas } \\
\text { tidak diatur dan merupakan pilihan kebijakan } \\
\text { manajeme. Akrual yang muncul akibat diskresi } \\
\text { manajemen atau berada di bawah kebijakan } \\
\text { manajemen. }\end{array}$ & (TACit/ TAit-1) - NDAit & Rasio \\
\hline $\begin{array}{l}\text { Tax Planning } \\
\text { (X4) }\end{array}$ & $\begin{array}{l}\text { proses merekayasa usaha dan transaksi wajib } \\
\text { pajak agar hutang pajak berada dalam jumlah } \\
\text { yang menimal, tetapi masih dalam bingkai } \\
\text { peraturan perpajakan. }\end{array}$ & $\frac{\text { Net } \text { Income }_{i t}}{\text { Pretax Income }(E B I T)_{i t}}$ & Rasio \\
\hline $\begin{array}{l}\text { Manajemen } \\
\text { Laba }(Y)\end{array}$ & $\begin{array}{l}\text { Suatu intervensi manajemen dengan sengaja } \\
\text { dalam proses penentuan laba, biasanya untuk } \\
\text { tujuan pribadinya. }\end{array}$ & $\begin{array}{l}1 \text { untuk perusahaan yang } \\
\text { berada dalam range small } \\
\text { profit firms dan } 0 \text { untuk } \\
\text { perusahaan yang berada } \\
\text { dalam range small loss } \\
\text { firms }\end{array}$ & Nominal \\
\hline
\end{tabular}

\section{Metode Analisis Data}

Metode yang digunakan untuk menguji hipotesis yaitu metode regresi logistik dengan menggunakan program SPSS versi 22. Manajemen laba (earnings management) dihasilkan dari persamaan regresi logistik berikut:

$$
L n \frac{E M i t}{1-E M}=\alpha+\beta_{1} \mathrm{CTE}_{i t}+\beta_{2} \mathrm{CAPT}_{i t}+\beta_{3} \mathrm{DA}_{i t}+\beta_{4} \mathrm{TP}_{i t}+\varepsilon_{i t}
$$

Keterangan:

$\operatorname{Ln} \frac{E M \text { it }}{1-E M}=$ Manajemen laba pada perusahaan $\mathrm{i}$

$\mathrm{CTE}_{i t}=$ Beban pajak kini perusahaan i pada tahun $\mathrm{t}$

CAPT $_{i t}=$ Cadangan aset pajak tangguhan perusahaan i pada tahun $\mathrm{t}$

$\mathrm{DA}_{i t} \quad=$ Discretionary accrual perusahaan i pada tahun $\mathrm{t}$

$\mathrm{TP}_{\text {it }} \quad=$ Tax planning perusahaan i pada tahun $\mathrm{t}$

$\alpha \quad=$ Konstanta

$\beta \quad=$ Koefisien Regresi Logistik

$\varepsilon_{i t} \quad=$ Term of error

Dasar pengambilan keputusan adalah dengan menggunakan tingkat signifikansi $5 \%$, maka:

a. Jika probabilitas $>0,05$, maka Ha ditolak sehingga hasil tidak signifikan.

b. Jika probabilitas $<0,05$, maka Ha diterima sehingga hasil signifikan.

\section{HASIL DAN PEMBAHASAN}




\subsection{Hasil Uji Regresi Logistik}

Uji Kelayakan Keseluruhan Model

Penilaian model fit dilakukan dengan membandingkan nilai antara -2 Log likelihood ($2 L L)$ pada awal (Block Number $=0)$, dimana model hanya memasukkan nilai -2 Log likehood dan konstanta, dengan nilai -2 Log likelihood (-2LL) pada akhir (Block Number $=1)$, dimana model memasukkan konstanta dan variabel bebas. Apabila nilai $-2 L L$ Block Number $=0>$ nilai -2LL Block Number = 1, maka menunjukkan model regresi yang baik (Ghozali, 2013).

Tabel 2 Hasil Uji Regresi Logistik untuk Keseluruhan Model

\begin{tabular}{|c|c|c|c|c|c|c|c|}
\hline \multicolumn{8}{|c|}{ Iteration History ${ }^{\mathrm{a}, \mathrm{b}, \mathrm{c}, \mathrm{d}}$} \\
\hline \multirow[b]{2}{*}{ Iteration } & & \multirow[b]{2}{*}{-2 Log likelihood } & \multicolumn{5}{|c|}{ Coefficients } \\
\hline & & & Constant & CTE & CAPT & $\mathrm{DA}$ & TRR \\
\hline \multirow{6}{*}{ Step 1} & 1 & 141,417 & $-2,640$ & 7,433 &,- 034 & 12,592 & 3,694 \\
\hline & 2 & 138,163 & $-3,880$ & 16,556 &,- 038 & 16,693 & 4,847 \\
\hline & 3 & 137,886 & $-4,324$ & 20,101 &,- 039 & 19,907 & 5,228 \\
\hline & 4 & 137,884 & $-4,369$ & 20,418 &,- 039 & 20,346 & 5,267 \\
\hline & 5 & 137,884 & $-4,369$ & 20,421 &,- 039 & 20,350 & 5,267 \\
\hline & 6 & 137,884 & $-4,369$ & 20,421 &,- 039 & 20,350 & 5,267 \\
\hline
\end{tabular}

a. Method: Enter

b. Constant is included in the model.

c. Initial -2 Log Likelihood: 158,627

d. Estimation terminated at iteration number 6 because parameter estimates changed by less than ,001

Sumber: Output SPSS 22.0

Pada tabel di atas, dapat dilihat literation history saat variabel independen di masukan ke dalam model dengan $\mathrm{n}=121$ dan degree of freedom $(\mathrm{df}) 116(\mathrm{df}=\mathrm{n}$ - variabel independen 1), chi-square $\left(\mathrm{X}^{2}\right)$ tabel pada df 116 dan probabilitas $0,05=142,138$. Nilai -2log Likelihood $(137,884)<$ chi-square $\left(\mathrm{X}^{2}\right)$ tabel $(142,138)$, maka hal ini menunjukkan bahwa model yang dihipotesiskan fit dengan data.

\section{Uji Hosmer and Lemeshow's Goodness of Fit Test}

Kelayakan dan kesesuaian model pada regresi logistik dapat dilihat dari pengujian Hosmer dan Lemeshow dan juga Classification plot. Pada pengujian Hosmer dan Lemeshow dilihat dari tabel Hosmer dan Lemeshow Test yang disajikan pada tabel dibawah ini :

\section{Tabel 3 Hasil Pengujian Hosmer dan Lemeshow Tests}

\begin{tabular}{|l|r|r|r|}
\hline \multicolumn{1}{|c|}{ Hosmer and Lemeshow Test } \\
\hline Step & Chi-square & df & \multicolumn{1}{c|}{ Sig. } \\
\hline 1 & 7,053 & & 8 \\
\hline
\end{tabular}

\section{Sumber: Output SPSS 22.0}

Tabel 3 menunjukan hasil pengujian Hosmer dan Lemeshow Test. Nilai Hosmer dan Lemeshow's Goodness of Fit Test lebih besar dari 0,05 yang berarti model mampu memprediksi nilai observasinya atau dapat di katakan model dapat di terima karena cocok dengan data observasinya. Tampilan output SPSS menunjukan besarnya nilai Hosmer dan Lemeshow's Goodness of Fit Test sebesar 7,053 dengan probabilitas signifikansi 0,531 yang nilainya diatas 0,05 dengan demikian dapat disimpulkan bahwa model dapat diterima. 


\section{Nagelkerke's R Square}

Nagelkerke's R Square memiliki interprestasi yang sama dengan koefisien determinasi. Penilaian Nagelkerke's R Square dapat dilihat dari model Summary pada tabel berikut ini:

\section{Tabel 4 Hasil Pengujian Negelkerke's R Square Test}

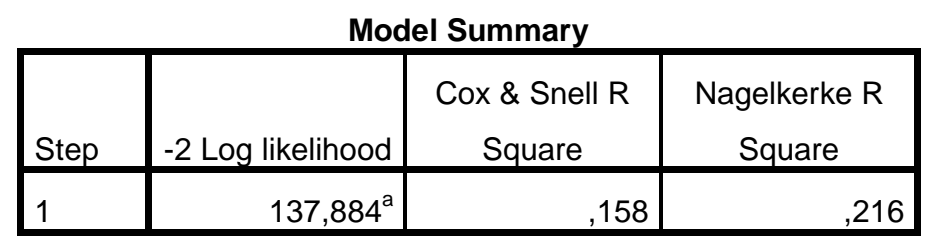

a. Estimation terminated at iteration number 6 because

parameter estimates changed by less than ,001.

Sumber: Output SPSS 22.0

Dapat dilihat dari output SPSS nilai Cox \& Snell R Square sebesar 0,158 dan nilai Nagelkerke's R Square adalah 0,216. Nilai R-squared pada model ini adalah 0,216 yang berarti varibilitas variabel dependen yang dapat dijelaskan oleh variabilitas variabel independen sebesar $21,6 \%$. Sedangkan, sisanya 78,4\% dipengaruhi oleh faktor lain diluar model penelitian. Hal ini disebabkan masih banyaknya faktor yang mempengaruhi manajemen laba yang tidak dimasukan dalam model penelitian ini, seperti profitabilitas, leverage, size, growth, dan lain-lain

\section{$\underline{\text { Tabel Klasifikasi }}$}

Classification Plot mencerminkan seberapa banyak kita dapat memprediksi dengan benar ketepatan model. Pada tabel klasifikasi hasil SPSS menunjukkan bahwa pada kolom prediksi yang mengungkapan perusahaan melakukan manajemen laba ada 121 data observasi, sedangkan pada baris hasil observasi sesungguhnya hanya ada 89 data observasi. Jadi, ketepatan model adalah 89/121 atau 73,6\%, hal tersebut dapat dilihat dari Tabel dibawah ini :

Tabel 5 Hasil Pengujian Classification Plot

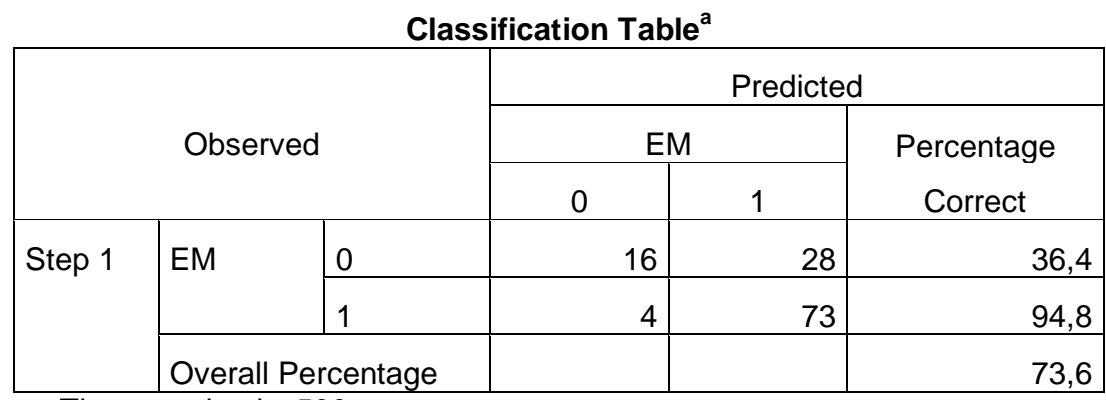

a. The cut value is ,500

Sumber: Output SPSS 22.0

\section{Menguji Koefisien Regresi}

Hasil pengujian regresi logistik, menunjukkan bahwa model regresi layak di pakai untuk menganalisis, pengujian dilakukan pada tingkat signifikansi $(\alpha)$ 5\%. Tabel 4.8 menampilkan variabel in the equation yang digunakan untuk menunjukan pengaruh 4 variabel independen terhadap perusahaan di Bursa Efek Indonesia yang yang melakukan tindakan manajemen laba. 
Berdasarkan hasil perhitungan pada Tabel 6 diperoleh hasil bahwa variabel independen yang diproksikan dengan beban pajak kini (CTE) menunjukkan tingkat signifikansi sebesar $0,023<0,05$ yang berarti beban pajak kini berpengaruh signifikan terhadap manajemen laba.

Tabel 6 Hasil Pengujian Variabel Independen

\begin{tabular}{|c|c|c|c|c|c|c|c|}
\hline \multicolumn{8}{|c|}{ Variables in the Equation } \\
\hline & & $\mathrm{B}$ & S.E. & Wald & df & Sig. & $\operatorname{Exp}(B)$ \\
\hline \multirow[t]{5}{*}{ Step $1^{a}$} & CTE & 20,421 & 8,973 & 5,180 & 1 & ,023 & 738950332,643 \\
\hline & CAPT &,- 039 & ,039 & 1,027 & 1 & ,311 & ,962 \\
\hline & DA & 20,350 & 23,979 & ,720 & 1 & ,396 & 688682163,466 \\
\hline & TRR & 5,267 & 2,257 & 5,445 & 1 & ,020 & 193,889 \\
\hline & Constant & $-4,369$ & 1,774 & 6,064 & 1 & ,014 & ,013 \\
\hline
\end{tabular}

a. Variable(s) entered on step 1: CTE, CAPT, DA, TRR.

Sumber: Output SPSS 22.0

Untuk variabel aset pajak tanguhan (CAPT) memiliki tingkat signifikansi sebesar 0,311 $>0,05$ yang berarti aset pajak tangguhan tidak berpengaruh terhadap manajemen laba. Selanjutnya variabel discretionary accrual (DA) memiliki nilai signifikansi sebesar 0,396 > 0,05 yang berarti discretinary accrual tidak berpengaruh terhadap manajemen laba. Untuk variabel tax planning (TRR) menunjukkan tingkat signifikansi sebesar $0,020<0,05$ yang berarti tax planning berpengaruh signifikan terhadap manajemen laba. Dengan demikian dapat disimpulkan bahwa variabel beban pajak kini (CTE) dan tax planning (TRR) memiliki pengaruh terhadap manajemen laba, sedangkan variabel aset pajak tangguhan (CAPT) dan discretionary accrual (DA) tidak memiliki pengaruh terhadap manajemen laba. Berdasarkan output tersebut, persamaan matematis dapat dinyatakan sebagai berikut:

$\operatorname{Ln} \frac{E M i t}{1-E M}=-4,369+20,421 \mathrm{CTE}_{i t}-0,039 \mathrm{CAPT}_{i t}+20,350 \mathrm{DA}_{i t}+5,267 \mathrm{TRR}_{i t}+\varepsilon_{i t}$

Koefisien pada regresi logistik akan sulit diinterpretasikan secara langsung karena hubungan antara probabilitas EM (manajemen laba) dan variabel independen adalah non-linier, sedangkan hubungan antara log dari odds dan variabel independen adalah linier. Oleh karena itu, dalam hal ini interpretasi terhadap koefisien variabel independen harus dilihat pengaruhnya terhadap log dari odds dan bukan terhadap probabilitas EM (manajemen laba). Sehingga persamaan matematisnya dapat disederhanakan menjadi:

Omnibus Test

$$
\begin{aligned}
\mathrm{EM}=0,013 & +738950332,643 \mathrm{CTE}_{i t}+0,962 \mathrm{CAPT}_{i t}+688682163,466 \mathrm{DA}_{i t} \\
& +193,889 \mathrm{TRR}_{i t}+\varepsilon_{i t}
\end{aligned}
$$

Pengujian ini digunakan untuk mengetahui seluruh variabel independen yang dimasukkan dalam model regresi secara bersama-sama berpengaruh terhadap variabel dependen yang diuji pada tingkat signifikansi 0,05 (Ghozali, 2013). Tabel 7 menampilkan omnibus test of model coefficients yang digunakan untuk menunjukan pengaruh 4 variabel independen terhadap manajemen laba.

Tabel 7 Hasil Pengujian Omnibus Tests of Model Coefficients Omnibus Tests of Model Coefficients 


\begin{tabular}{|rl|r|r|r|}
\hline & & Chi-square & \multicolumn{1}{|c|}{ df } & \multicolumn{1}{c|}{ Sig. } \\
\hline Step 1 & Step & 20,743 & 4 &, 000 \\
& Block & 20,743 & 4 &, 000 \\
& Model & 20,743 & 4 &, 000 \\
\hline
\end{tabular}

Sumber: Output SPSS 22.0

Pada tabel 7 dapat dilihat hasil chi-square hitung 20,743 > chi-square tabel 9,488 hal ini menunjukkan bahwa secara simultan beban pajak kini, aset pajak tangguhan, discretionary accrual, dan tax planning berpengaruh terhadap manajemen laba. Dan dapat dilihat nilai signifikansinya $0,000<0,05$ maka dapat disimpulkan beban pajak kini, aset pajak tangguhan, discretionary accrual, dan tax planning berpengaruh signifikan terhadap manajemen laba.

\subsection{Pembahasan}

Pengaruh Beban Pajak Kini, Aset Pajak Tangguhan, Discretionary Accrual, dan Tax Planning Terhadap Manajemen Laba

Hasil pengujian omnibus test of model coefficients menunjukkan hasil chi-square hitung 20,743 > chi-square tabel 9,488 hal ini menunjukkan bahwa secara simultan beban pajak kini, aset pajak tangguhan, discretionary accrual, dan tax planning berpengaruh terhadap manajemen laba. Kemudian karena signifikansinya $0,000<0,05$ maka dapat disimpulkan beban pajak kini, aset pajak tangguhan, discretionary accrual, dan tax planning berpengaruh signifikan terhadap manajemen laba. Maka hipotesis pertama diterima yang artinya secara simultan beban pajak kini, aset pajak tangguhan, discretionary accrual, dan tax planning berpengaruh signifikan terhadap manajemen laba.

Hasil output SPSS juga memberikan nilai Negelkerke $\mathrm{R}^{2}$ sebesar 0,216 . Hasil ini berarti variabilitas variabel dependen (manajemen laba) yang dapat dijelaskan oleh variabilitas variabel independen (beban pajak kini, aset pajak tangguhan, discretionary accrual, dan tax planning) sebesar $21,6 \%$. Sedangkan sisanya 78,4\% dipengaruhi oleh faktor lain diluar model penelitian. Hal ini disebabkan masih banyaknya faktor yang mempengaruhi manajemen laba yang tidak dimasukan dalam model penelitian ini seperti profitabilitas, leverage, size, growth, dll.

\section{Pengaruh Beban Pajak Kini Terhadap Manajemen laba}

Hasil pengujian regresi logistik menunjukkan tingkat signifikansi beban pajak kini sebesar $0,023<0,05$ yang berarti beban pajak kini berpengaruh signifikan terhadap manajemen laba. Maka hipotesis kedua diterima yang artinya terdapat pengaruh antara beban pajak kini terhadap manajemen laba.

Koefisien regresi bertanda positif sebesar 20,421 yang berarti beban pajak kini memiliki arah positif terhadap manajemen laba. Hal ini menjelaskan bahwa semakin besar beban pajak kini maka semakin besar pula kecenderungan manajemen melakukan manajemen laba. Hasil ini konsisten dengan hasil penelitian sebelumnya yaitu Deviana (2010), Widhiastuti (2013), serta Triono (2014) yang menyatakan beban pajak kini berpengaruh signifikan terhadap manajemen laba. Adapun beban pajak kini mampumendeteksi kemungkinan terjadinya manajemen laba karena beban pajak kini merefleksikan penghasilan kena pajak yang merupakan hasil rekonsiliasi beda waktu sekaligus beda tetap terhadap laba akuntansi. Namun hal ini perlu adanya pembuktian kembali mengingat beban pajak kini tidak secara langsung merefleksikan perbedaan antara akuntansi dan pajak. 


\section{Pengaruh Aset Pajak Tangguhan Terhadap Manajemen laba}

Hasil pengujian regresi logistik menunjukkan tingkat signifikansi aset pajak tangguhan sebesar 0,311 $<0,05$ yang berarti aset pajak tangguhan tidak berpengaruh signifikan terhadap manajemen laba. Maka hipotesis ketiga ditolak yang artinya tidak terdapat pengaruh antara aset pajak tangguhan terhadap manajemen laba.

Hasil ini konsisten dengan penelitian terdahulu oleh Suranggane (2007), Dewi dan Feni (2012), Perwita, dkk (2013) dan Erwati,dkk (2013) yang menyatakan aset pajak tangguhan tidak berpengaruh terhadap manajemen laba. Hasil penelitian ini bertentangan dengan penelitian yang dilakukan oleh Bauman et al. (2001), dan Widiastuti dan Elsa (2011) yang menyatakan bahwa aset pajak tangguhan pengaruh terhadap manajemen laba.

Ada beberapa hal yang dapat dijadikan alasan mengapa manajemen perusahaan di Indonesia tidak memanfaatkan cadangan aset pajak tanguhan untuk merekayasa laba. Pertam a, karena adanya keterkaitan yang erat antara cadangan aset pajak tangguhan dengan ketentuan perpajakan, maksudnya, bila manajer memanfaatkan cadangan aset pajak tangguhan pada laporan keuangan komersial untuk melakukan manajemen laba, maka hal ini dapat berimbas pada laporan keuangan fiskalnya karena aset pajak tangguhan yang dilaporkan pada laporan keuangan komersial dalam jangka panjangnya harus sama dengan laporan keuangan fiskalnya; sehingga, manajer harus lebih memutar otak agar jumlah cadangan aset pajak tangguhan yang direkayasa tidak menyebabkan pembayaran pajak yang besar yang dapat merugikan perusahaan. Kedua pada saat pengauditan laporan keuangan komersial, apabila perusahaan melakukan manipulasi atas cadangan aset pajak tangguhan, maka hal ini dapat dideteksi oleh auditor intern, yang kemudian diperbaiki oleh manajemen, maka saat auditor ektern memeriksa laporan keuangan komersialnya, hal itu tidak akan nampak karena sudah benar adanya atau sudah mencerminkan keadaan yang sesuai dengan standar akuntansi keuangan.

\section{Pengaruh Discretionary Accrual Terhadap Manajemen laba}

Hasil pengujian regresi logistik menunjukkan tingkat signifikansi discretionary accrual sebesar 0,396 < 0,05 yang berarti discretionary accrual tidak berpengaruh signifikan terhadap manajemen laba. Maka hipotesis keempat ditolak yang artinya tidak terdapat pengaruh antara discretionary accrual terhadap manajemen laba.

Hasil ini konsiten dengan penelitian terdahulu oleh Erwati, dkk (2013) dan Dewi dan Feni (2012) yang menyatakan bahwa dixcretionary accrual tidak pengaruh terhadap manajemen laba. Hasil penelitian ini bertentangan dengan penelitian yang dilakukan oleh Suranggane (2007), Subagyo (2011), Widiastuti dan Elsa (2011), dan Perwita, dkk (2013) yang menyatakan dicretionary accrual berpengaruh terhadap manajemen laba.

\section{Pengaruh Tax Planning Terhadap Manajemen laba}

Hasil pengujian regresi logistik menunjukkan tingkat signifikansi tax planning sebesar $0,020<0,05$ yang berarti tax planning berpengaruh signifikan terhadap manajemen laba. Maka hipotesis kelima diterima yang artinya terdapat pengaruh antara tax planning terhadap manajemen laba.

Hasil ini konsisten dengan penelitian terdahulu oleh Sumomba (2010), Ulfa (2013), dan Khotimah (2014) yang menyatakan tax planning berpengaruh terhadap manajemen laba. Namun hasil penelitian ini bertentangan dengan penelitian yang dilakukan oleh Aditama dan Purwaningsih (2013) dan Singkiati (2015) yang menyatakan bahwa tax planning tidak pengaruh terhadap manajemen laba.

Hal yang dapat dijadikan alasan pengaruh tax planning terhadap manajemen laba pada penelitian ini adalah karena perencanaan pajak merupakan langkah awal dalam manajemen 
pajak. Manajemen pajak itu sendiri merupakan sarana untuk memenuhi kewajiban perpajakan dengan benar tetapi jumlah pajak yang dibayarkan dapat ditekan seminimal mungkin untuk memperoleh laba dan likuiditas yang diharapkan. Perencanaan pajak umumnya selalu dimulai dengan meyakinkan kejadian tersebut mempunyai dampak pajak, apakah dampak tersebut dapat diupayakan untuk dikecualikan atau dikurangi jumlah pajaknya. Selanjutnya, apakah pembayaran pajak tersebut dapat ditunda. Salah satu perencanaan pajak adalah dengan cara mengatur seberapa besar laba yang dilaporkan, sehingga masuk dalam indikasi adanya paktik manajemen laba.

\section{SIMPULAN DAN SARAN \\ Simpulan}

1. Beban pajak kini berpengaruh terhadap manajemen laba.

2. Aset pajak tangguhan tidak berpengaruh terhadap manajemen laba pada perusahaan manufaktur.

3. Discretionary accrual tidak berpengaruh terhadap manajemen laba pada perusahaan manufaktur

4. Tax planning berpengaruh terhadap manajemen laba pada perusahaan manufaktur

\section{Saran}

Keterbatasan periode pengamatan yang hanya mengambil lingkup empat tahun, sehingga hasil penelitian belum dapat mencerminkan kondisi sesungguhnya sehingga disarankan untuk penelitian berikutnya untuk memperpanjang masa pengamatan untuk lebih menangkap fenomena penelitian yang lebih luas. Penelitian ini hanya fokus pada perusahaan manufaktur, untuk selanjutnya penelitian ini dapat dikembangkankan untuk meneliti sektor lain di Bursa Efek di Indonesia.

\section{DAFTAR PUSTAKA}

Abdul Halim dan Bambang, Supomo. 2005. Akuntansi Manajemen. Yogyakarta: BPFE.

Aditama, Ferry, dan Purwaningsih. 2013. Pengaruh Perencanaan Pajak Terhadap Manajemen Laba Pada Perusahaan Nonmanufaktur yang Terdaftar di Bursa Efek Indonesia. Skripsi Program Sarjana Universitas Atma Jaya Yogyakarta

Agoes, Sukrisno dan Trisnawati Estralia. 2007. Akuntansi Perpajakan. Edisi Dua: Salemba Empat.

Belkaoi, Ahmed R. 2007. Accounting Theory. Edisi Lima. Jakarta: Salemba Empat.

Budiman, Taufik. 2013. Pengaruh Beban Pajak dan Akrual Terhadap Indikasi Adanya Praktik Manajemen Laba. Jurnal Universitas Komputer Indonesia.

Damayanti, Thersia. 2008. Perbandingan Akrual dan Pajak Tangguhan dalam Pengujian Aliran Kas Masa Datang dan Return Saham. Jurnal Akuntansi/Tahun XII, No. 03. pp 250-259.

Dewi, Sofia Prima dan Feni. 2012. Pengaruh Aset Pajak Tangguhan, Diskresioner Akrual, Tingkat Hutang, dan Ukuran Perusahaan Terhadap Manajemen Laba pada Perusahaan Manufkatur yang Terdaftar di Bursa Efek Indonesia. Jurnal Fakultas Ekonomi Universitas Tarumanegara.

Deviana, Birgita, 2010. Kemampuan Beban Pajak Tangguhan dan Beban Pajak Kini dalam Mendeteksi Manajemen Laba pada saat Seasoned Equity Offerings. Jurnal Fakultas Ekonomi Universitas Diponegoro, Semarang.

Erwati, Misni, Wiwik Tiswiyanti, dan Yuliusman. 2013. Kemampuan Beban Pajak Tangguhan, Aset Pajak Tangguhan, dan Akrual dalam Memprediksi Indikasi Praktik 
Manajemen Laba pada Perusahaan Manufaktur yang Terdaftar di Bursa Efek Indonesia Tahun 2009-2011. Manajemen Terapan dan Keuangan, Vol. 2, No.3, Hal. 253-373.

Ghozali, Imam. Aplikasi Analisis Multivariate dengan Program SPSS. Semarang : BP Undip, 2013.

Gudono.2012. Teori Organisasi. BPFE .Yogyakarta

Gunadi. 2009. Akuntansi Pajak Edisi Revisi 2009. Jakarta: Gramedia Widiasarana Indonesia.

Harjito, D. Agus dan Martono. 2013. Manajemen Keuangan. BPFE, Yogyakarta.

Hamzah, Ardi. 2014. Deteksi Earnings Management Melalui Beban Pajak Tangguhan, Akrual dan Arus Kas Operasi: Studi Pada Perusahaan Real Estate dan Property yang Terdaftar di Bursa Efek Indonesia Tahun 2006-2008. Neo-bis: Jurnal Berkala Ilmu Ekonomi, Volume 8, No 1.

Irreza dan Yulianti. 2012. Penggunaan Komponen Pembentuk Pajak Tangguhan Dalam Mendeteksi Manajemen Laba. Jurnal Akuntansi dan Keuangan Indonesia, No. 1, 68-82.

Jensen, M.C. and W.F.Meckling. "Theory of the Firm : Managerial Behavior, Agency Cost and Ownership Structure.” Journal of Financial Economic Vol.3 Oktober (1976).

Khotimah, Husnul. 2014. Pengaruh Perencanaan Pajak Terhadap Manajemen Laba. Esensi: Jurnal Bisnis dan Manajemen, Volume 4, No 2.

Perwita, Andarumi Mustikaning, Titiek Puji Astuti, dan Agung Nurmansyah. 2013. Analisis Beban Pajak Tangguhan, Aset Pajak Tangguhan, dan Akrual Sebagai Prediktor Manajemen Laba pada Perusahaan Manufaktur yang Terdaftar di Bursa Efek Indonesia Periode 2009-2013.

Philips, Pincus and S.O. Rego. 2003. Earnings Management : New Evidence Based on Diferred Tax Expense. The Accounting Review. No. 78 pp 491-521.

Rahmi, Aulia. 2013. Kemampuan Beban Pajak Tangguhan dan Beban Pajak Kini Dalam Mendeteksi Manajemen Laba Pada Saat Seasoned Equity Offerings. Jurnal Akuntansi, Volume 1, No 3.

Satwika, Anisa dan Theresia Woro Damayanti. 2005. Deteksi Manajemen Laba melalui Beban Pajak Tangguhan. Jurnal Ekonomi dan Bisnis Indonesia. Vol. XI No.1.

Scott, W.R. 2006. Financial Accounting Theory. PrenticeHall International.

Suandy, Erly. 2011. Perencanaan Pajak. Salemba Empat. Jakarta

Subagyo, Oktavia dan Mariana. 2011. Pengaruh Disretionary Accrual dan Beban Pajak Tangguhan Tehadap Manajemen Laba. Jurnal Akuntansi, Volume 11, Nomor 1.

Sumomba, Christina Ranty. 2010. Pengaruh Beban Pajak Tangguhan dan Perencanaan Pajak terhadap Praktik Manajemen Laba pada Perusahaan Manufaktur yang Terdaftar di Bursa Efek Indonesia. Skripsi Program Sarjana Universitas Atma Jaya Yogyakarta.

Suranggane, Zulaikha. 2007. Analisis Aktiva Pajak Tangguhan dan Akrual Sebagai Prediktor Manajemen Laba: Kajian Empiris pada Perusahaan Manufaktur yang Terdaftar di BEJ. Jurnal Akuntansi dan Keuangan Indonsia, Vol.4, No. 1, Hal. 77-94.

Ulfah, Yana. 2013. Pengaruh Beban Pajak Tangguhan dan Perencanaan Pajak Terhadap Praktik Manajemen Laba. Prosiding Simposium Nasional Perpajakan, 4. Samarinda.

Widhiastuti, Nur Indah. 2013. Kemampuan Beban Pajak Kini, Pajak Tangguhan dan Return on Assets dalam Mendeteksi Manajemen Laba Pada Perusahaan Pertambangan yang Terdaftar di Bursa Efek Indonesia. Other thesis, UPN "Veteran" Yogyakarta.

Zain, Mohammad.2005. Manajemen Perpajakan. Jakarta: Salemba Empat. 